\title{
INSTRUMENTAL NEUTRON ACTIVATION ANALYSIS OF INKA AND LOCAL POTTERY FROM NORTHERN CHILE'S ATACAMA DESERT
}

\author{
Verónica I. Williams ${ }^{\mathrm{a}}$ \\ Calogero M. Santoro ${ }^{\mathrm{b}, *}$ \\ Robert J. Speakman ${ }^{\mathrm{c}}$ \\ Michael D. Glascock ${ }^{\mathrm{d}}$ \\ Álvaro Luis Romero Guevara ${ }^{\mathrm{e}}$ \\ Daniela Valenzuela ${ }^{\mathrm{f}}$ \\ Vivien G. Standen ${ }^{\mathrm{g}}$ \\ Terence N. D`Altroy ${ }^{\mathrm{h}}$
}

${ }^{a}$ Universidad de Buenos Aires. Consejo Nacional de lnvestigaciones Científicas y Técnicas (CONICET). Instituto de las culturas (IDECU).Facultad Filosofía y Letras, Buenos Aires, Argentina, veronicaw33@gmail.com.

${ }^{\mathrm{b}}$ Universidad de Tarapacá, Instituto de Alta Investigación, Laboratorio de Arqueología y Paleoambiente, Antofagasta 1520, Arica, Chile, calogero_santoro@ yahooo.com.

${ }^{\mathrm{c}}$ Center for Applied Isotope Studies. The University of Georgia, 120 Riverbend Rd., Athens, GA 30602, archsci@uga.edu

d Archaeometry Laboratory, Research Reactor Center, University of Missouri, Columbia, MO 65211, glascockm@missouri.edu.

e Oficina Técnica del Consejo de Monumentos Nacionales, Región de Arica y Parinacota, alrogu@yahoo.com.

${ }^{\mathrm{f}}$ Departamento de Antropología, Universidad Alberto Hurtado, Almirante Barroso 10, Santiago 6500620, Chile,dvalenzuel@uahurtado.cl.

g Departamento de Antropología, Universidad de Tarapacá, 18 de Septiembre 2222, Arica, Chile; vivien.standen@gmail.com.

${ }^{\mathrm{h}}$ Dept. of Anthropology, Director, Columbia Center for Archaeology' Columbia University, NY; tnd1@columbia.edu.

* Corresponding author. Tel./fax: +56 58 220-5896.

E-mail address: calogero_santoro@yahoo.com (C. Santoro). 


\section{ABSTRACT}

This paper presents the results of bulk chemical compositional analyses of ceramic pastes through Instrumental Neutron Activation Analysis (INAA), which is the most precise method available for this kind of research. The analyses were carried out on 94 fragments of pottery from several archaeological sites in northern Chile's Atacama Desert (Fig 1, Table A.1). We aimed to examine the possible origins of pottery vessels distinguished by Inka and local styles within the process of the Inka State expansion into the territories south of Cusco, known as Collasuyu.

On the basis of these analyses, we discuss the idea that the State introduced to the zone pottery with Inka iconographic styles from the Lake Titicaca region (more than $500 \mathrm{~km}$ away). But, more important, the State seems to have encouraged the replication of State pottery standards by local artisans, who consciously or unconsciously maintained certain traditional procedures. This means that skilled local artisans imitated Inka iconographic style but using paste of local origin. These results show the importance of archaeometric analysis of high-prestige fine Inka and local pottery as it sheds light on how the State managed their political strategies, their impact on the prehistoric polities of northern Chile (NCh).

Keywords: INAA, Imperial and local reproduced Inka pottery styles, Southern Andes, interregional interaction 


\section{Introduction}

\subsection{Regional Background and Relevant Research Questions}

The expansion of the Inka throughout the Andes has been highlighted though the presence of conspicuous cultural material that included architecture, textiles, metal objects and distinctive Inka polychrome pottery, among other raw items (Alconini, 2013; Hyslop, 1990). We believe that marginal territories like the northern Chile were incorporated into the empire, although no major architectural projects were undertaken (Adán and Uribe, 2005; Muñoz and Chacama, 2010; Santoro, et al., 2010b; Uribe and Urbina, 2009; Williams, et al., 2009; Zori and Urbina, 2014). We think that pottery played an important role in this process, both by moving high-prestige fine pottery from regional productive political centers, and by endorsing State standard pottery making techniques for local replicas. More specifically we propose that certain vessels from State pottery productive centers in the Titicaca region, more than $500 \mathrm{~km}$ away, were brought into the coast and valleys of northern Chile by long distance networks of exchange and alliances (Ballester and Gallardo, 2011; Romero, 2002; Santoro, et al., 2010a; Villanueva, 2015).

We particularly refer to the elegant Inka vessels and their provincial versions that were produced either through the labor-intensive efforts of local potters or the creation of pottery productive centers staffed by specialized artisans who served the State as mitmaqkuna (Espinoza Soriano, 1970; Murra, 1978). It is uncertain, however, where Inka vessels were produced and what mechanisms of distribution and consumption were carried out. At State administrative centers, Inka pottery was repeatedly used for commensal hospitality, to serve beer and food, or as containers for offerings at shrines and human burials (Ceruti and Reinhard, 2009; Morris, 1995; Morris and Thompson, 1985). In provincial territories such as Northwest Argentina (NWA) and northern Chile (NCh), Cusco polychrome and its variations were used in everyday activities, as 
well as in specialized contexts, such as particular compounds in provincial centers, cemeteries, and shrines. The Inka used these prestige goods to enhance the role of the State as sponsor and other managerial policies applied by the Inka to maintain and enhance their power and control over constantly expanding territories (Calderari and Williams, 1991; Ceruti and Reinhard, 2009; Couso, et al., 2011; D'Altroy, et al., 2007; Raffino, 2004; Williams, 2010; Williams and Lorandi, 1986).

Inka polychrome ceramics varied in style and manufacturing techniques from one province to the next (Calderari and Williams, 1991; Hayashida, et al., 2003; Julien, 1983; Morris, 1972). This was the consequence of the spatially limited circulation of Cusco pots with polychrome styles and the reliance on local potters for its production (Alconini, 2013; D'Altroy and Bishop, 1990; Spurling, 1992). Conversely, great stylistic and compositional variation among the provinces should be expected. One way to sort this out is through instrumental neutron activation analysis (INAA), aiming to identify whether Inka style vessels were locally made, or whether they were brought from specialized centers of production and distribution over a large regional area.

In short our research is intended to improve the knowledge and explanations for the political milieu of the Inka State government and productive policies enforced across provinces. In particular, we looked for regional patterns of ceramic production and distribution during the Inka period in an attempt to demonstrate that, among the transformations brought about by the Inka State, pottery production was changed by introducing new technologies and iconography that were reworked by local artisans who, consciously or unconsciously, incorporated certain traditional procedures. 


\subsection{Regional Setting}

The territories of the Pacific littoral, the coastal valleys, high Andean valleys and high Andean plateau of NCh (Fig. 1) maintained a relatively low population density as general and chronic hyper arid conditions limited the possibilities a large-scale and intensive agricultural and pastoral production. This would seem to explain the minimal State investment in those territories. Consequently, considering the environmental constraints and applying Murra's (2002) vertical model, Llagostera (2010) has suggested that the Inka State controlled the territories of NCh through Caranga, Lupaqa, Colla, and Pacaje political groups from the Titicaca basin. These polities had demographic and economic capacities to confront the problems of maintaining productive operations over territories outside of their native lands in the highland, during preInka times (Covey, 2000; Murra, 2002; Santoro, et al., 2010b; Schiappacasse, et al., 1989).

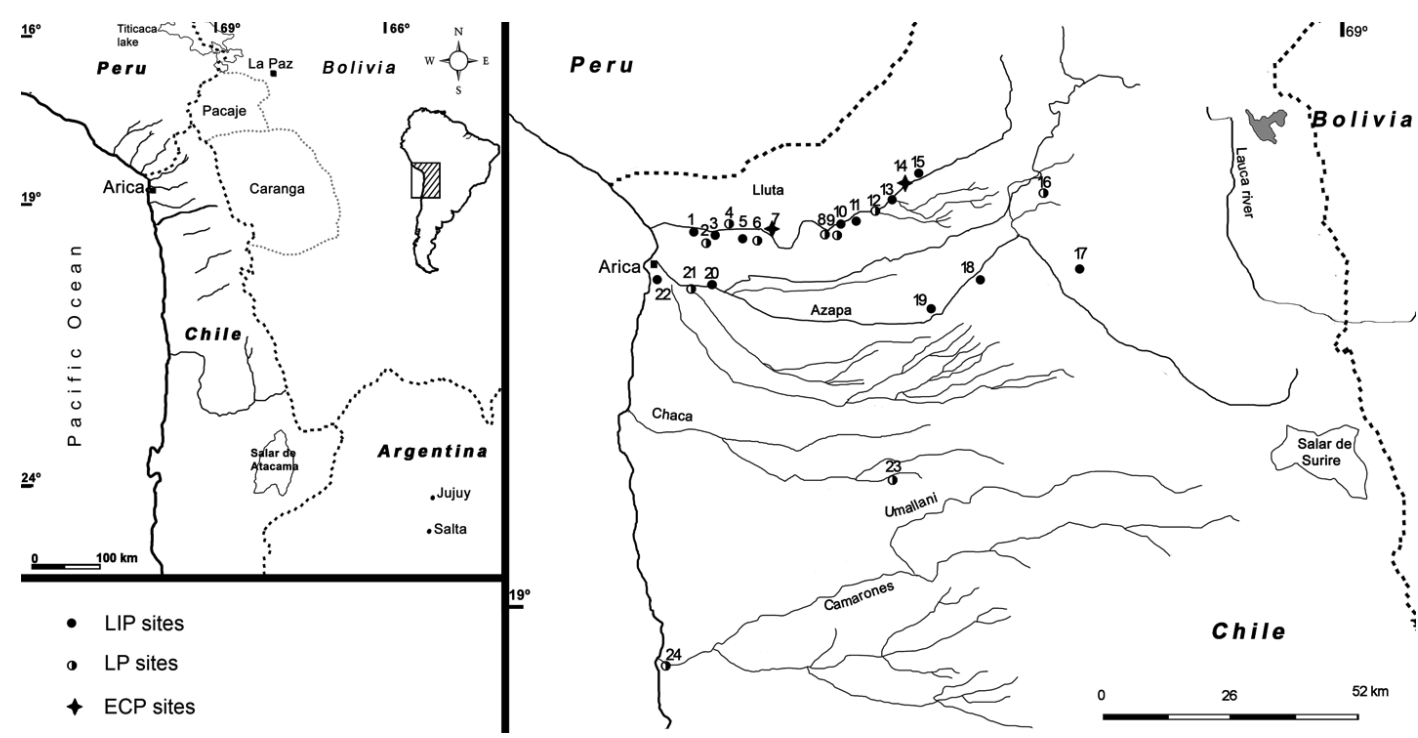

Fig. 1. Archaeological sites referred in this study: (1) Lluta 1 (Santa Lucia), (2) Lluta 54 (Huaylacán), (3) Lluta 12 (Oleoducto) (4) Lluta 34 (Caquena Este), (5) Lluta 35 (Rosario 1), (6) 36 (Rosario 2), (7) Lluta 3, (Parcela Villa Olga), (8) Lluta 47 (Bocanegra Bajo), (9) Lluta 48 (Bocanegra km 40), (10) Lluta 45 (Cardones), (11) Lluta 44 (Molino Calacala), (12) Lluta 41 (Chapisca), (13) Lluta 19 (Sora Sur), (14) Lluta 24 (Challallapo A), (15) Lluta 21 (Millune), (16) Tambo Zapahuira, (17) Huaihuarani, (18) Azapa-58 (Achuyo), (19) Azapa-50 (Chilpe), (20) Azapa-8 (San Miguel), (21) Azapa-15 (Alto Ramírez), (22) Playa Miller-4, (23) Cachicoca, (24) Camarones 9 (drawn by Paola Salgado) (see references in Table A.1). 
Before Inka control, the societal groups of NCh and southernmost Peru were sociopolitically interdependent, whereas political and economic arrangements between local leaders did not trigger the formation of highly hierarchical and stratified social structures ruled by paramount chiefs. Instead, each local leader controlled small segments of territories and people within a coastal valley, a possible section in the coast, and a section in the upper part of the valley (Romero, 2002; Santoro, et al., 2010b). The highlands were part of a different political system. The political and economic alliances between pre-Inka polities was sealed through certain cultural actions reflected, for instance, in the use of common iconography for pottery, textiles, and rock art, which helped to create and maintain social bonds, internal negotiations, and eventually solve disputes. It may also have created a common front to negotiate with, or contend against, the more powerful and larger Altiplano or highland groups, which were permanently eager to gain access to the attractive and diverse resources of the tropical forest and coastal Pacific lowlands (Murra, 2002).

This local political network started to be transformed in the $14^{\text {th }}$ century when Topa Inka Yupangui conquered the province of Pacaxes, a territory contiguous to the province of Arica. Topa Inka carried out some geopolitical reorganization, designating land for maize cultivation in the valleys and coast of Arica and Arequipa (Jiménez de la Espada, 1965). This political decision may have allowed Altiplano people to control the lowlands, a political and economic desire that could not be materialized before as they did not have the political and economic power to maintain long-distance territorial control (Covey, 2000; Llagostera, 2010; Murra, 2002; Stanish, 1992).

\subsection{Pottery styles and chronology}

We present the pottery styles from NCh for the Late Intermediate Period (LIP, A.D. 1,000 - 
1,400), the Late Period (LP, A.D. 1,400 - 1,530) and the Posthipanic Period (PHP, A.D. 1,530 1,700). Three stylistic clusters are known for the LIP: Arica, Serrano, and Black on Red. It is important to note that these styles are no exclusively of the LIP because, as seen in many parts of the Andes, local pre-Inka style continued during the LP (Ixer, et al., 2014; Santoro, 2016;

Schiappacasse, et al., 1989; Schiappacasse and Niemeyer, 1989; Sillar and Dean, 2002; Williams, 2004). Conversely, LIP pottery styles could be present at both LIP and LP sites. In contrast, Inka pottery styles will be only present at LP sites. The PHP, represented by the Indigenous Post Hispanic style, are found at LP site either (see Table A.1).

1.3.1. Late Intermediate Period (A.D. 1,000 to 1,400) pottery styles

The LIP pottery is composed by Arica, Serrano and Black/Red clusters, including different styles, which are summarized in Tables 1 and 2 .

Table 1. Paste characteristics of Late Intermediate Period pottery clusters and styles (after Romero 2004; Santoro et al. 2001).

\begin{tabular}{|l|l|l|l|}
\hline \multicolumn{1}{|c|}{ Cluster } & \multicolumn{1}{|c|}{ Styles } & \multicolumn{1}{c|}{ Origin } & \multicolumn{1}{c|}{ Paste* } \\
\hline Arica & $\begin{array}{l}\text { San Miguel, } \\
\text { Pocoma and } \\
\text { Gentilar }\end{array}$ & $\begin{array}{l}\text { Local previous pottery } \\
\text { tradition }\end{array}$ & $\begin{array}{l}\text { Standard 400: a rather rough temper paste, with medium density of } \\
\text { quartz temper and rocks of black and gray color, in similar } \\
\text { proportions fired in a regular oxidizing environment. } \\
\text { Standard 100: has similar density and size temper to those of } \\
\text { Standard 400 and 500. This paste is used in domestic pottery. }\end{array}$ \\
\hline Serrano & Charcollo & $\begin{array}{l}\text { High Andes valleys of Arica } \\
\text { and in the highland of Tacna }\end{array}$ & $\begin{array}{l}\text { Standard 500: hard paste burned in an oxidant environment; show a } \\
\text { fine temper of white, orange, or brown color }\end{array}$ \\
\hline Black/Red & Chilpe & Highlands & $\begin{array}{l}\text { Standard 220: fine grain clay and temper burned at high temperature } \\
\text { in an oxidant firing }\end{array}$ \\
\hline
\end{tabular}


Table 2. Late Intermediate Period pottery styles (after Uribe 1999, Santoro et al. 2001, and Romero 2002, 2005)

\begin{tabular}{|c|c|c|c|c|c|c|}
\hline Style & Paste & Decoration/color & Designs & $\begin{array}{c}\text { Surface } \\
\text { treatment }\end{array}$ & $\begin{array}{c}\text { Common } \\
\text { forms }\end{array}$ & Varieties \\
\hline $\begin{array}{l}\text { San } \\
\text { Miguel }\end{array}$ & $\begin{array}{l}\text { Standard } \\
400\end{array}$ & $\begin{array}{l}\text { Tricolor. Red and } \\
\text { black, over a white } \\
\text { coat }\end{array}$ & $\begin{array}{l}\text { Discontinuous decoration, } \\
\text { in fields or panels, } \\
\text { predominantly } \\
\text { quadripartition. Geometric } \\
\text { motifs: sawn, zigzag, } \\
\text { scrolls, spirals, wavy lines }\end{array}$ & $\begin{array}{l}\text { Coated } \\
\text { polished }\end{array}$ & $\begin{array}{l}\text { Jars, jugs, } \\
\text { bowls and } \\
\text { mates }\end{array}$ & \\
\hline $\begin{array}{l}\text { Pocoma } \\
\text { (Pocoma- } \\
\text { Gentilar) }\end{array}$ & $\begin{array}{l}\text { Standard } \\
400\end{array}$ & $\begin{array}{l}\text { Bicolor. Red and } \\
\text { black over a } \\
\text { burnished "natural } \\
\text { dull terracotta" } \\
\text { surface without slip }\end{array}$ & $\begin{array}{l}\text { Continuous decoration } \\
\text { predominance of } \\
\text { tripartition. Sawn in } \mathrm{V} \text {, } \\
\text { circles, scrolls } \mathrm{S} \text {, crosses, } \\
\text { hooks, triangles }\end{array}$ & $\begin{array}{l}\text { Uncoated } \\
\text { polished }\end{array}$ & $\begin{array}{l}\text { Mates and } \\
\text { pitchers }\end{array}$ & \\
\hline $\begin{array}{l}\text { Gentilar } \\
\text { (Pocoma } \\
\text { Gentilar } \\
\text { B) }\end{array}$ & $\begin{array}{l}\text { Standard } \\
400\end{array}$ & $\begin{array}{l}\text { Tricolor. Black, red, } \\
\text { and white applied } \\
\text { over a burnished } \\
\text { reddish surface, or } \\
\text { discontinuous panels } \\
\text { with red slip }\end{array}$ & $\begin{array}{l}\text { Continuous decoration, } \\
\text { predominance of tripartition } \\
\text { with greater complexity in } \\
\text { the form and compositions } \\
\text { of designs: triangles, } \\
\text { spirals, wavy lines, crosses, } \\
\text { diamonds, biomorphic } \\
\text { motifs }\end{array}$ & $\begin{array}{l}\text { Uncoated } \\
\text { polished }\end{array}$ & Jars & \\
\hline Charcollo & $\begin{array}{l}\text { Standard } \\
500\end{array}$ & $\begin{array}{l}\text { Red irregular lines or } \\
\text { spots over a natural } \\
\text { brownish surface }\end{array}$ & $\begin{array}{l}\text { No recognizable design } \\
\text { pattern: spots of sprinkled } \\
\text { aspect, diluted lines, and } \\
\text { thick red spots an } \\
\text { brushstrokes }\end{array}$ & $\begin{array}{l}\text { Smoothed } \\
\text { with frequent } \\
\text { brushing }\end{array}$ & $\begin{array}{l}\text { Jars and } \\
\text { pots }\end{array}$ & $\begin{array}{l}\text { Serrano Crude Red } \\
\text { variety: pale color } \\
\text { covered with an } \\
\text { irregular application } \\
\text { of red slip both in } \\
\text { the interior and the } \\
\text { exterior of the } \\
\text { vessels }\end{array}$ \\
\hline Chilpe & $\begin{array}{l}\text { Standard } \\
220\end{array}$ & $\begin{array}{l}\text { Bicolor. Black motifs } \\
\text { over a red surface } \\
\text { natural or painted }\end{array}$ & $\begin{array}{l}\text { Geometric designs: spirals, } \\
\text { lines with triangles, serpent- } \\
\text { like lines, crosses, and } \\
\text { semi-circles; drawn parallel } \\
\text { and close to the rim, and } \\
\text { inside of the vessels }\end{array}$ & $\begin{array}{l}\text { Polished with } \\
\text { or without red } \\
\text { slip }\end{array}$ & bowls & $\begin{array}{l}\text { Perpendicular } \\
\text { Black/Red variety: } \\
\text { straight, diagonal, } \\
\text { waving lines, } \\
\text { triangles, and } \\
\text { crosses } \\
\text { perpendicular to the } \\
\text { rim } \\
\text { Vilavila variety: } \\
\text { combination of } \\
\text { straight and } \\
\text { undulating lines, } \\
\text { parallel to the rim, } \\
\text { repeated at certain } \\
\text { intervals }\end{array}$ \\
\hline
\end{tabular}

The Arica cluster encompasses three classic polychrome styles: San Miguel, Pocoma and Gentilar (Fig. 2), which evolved from the previous local pottery tradition (Romero, 2002;

Romero, 2005; Santoro, et al., 2001; Schiappacasse, et al., 1989; Uribe, 1999). 


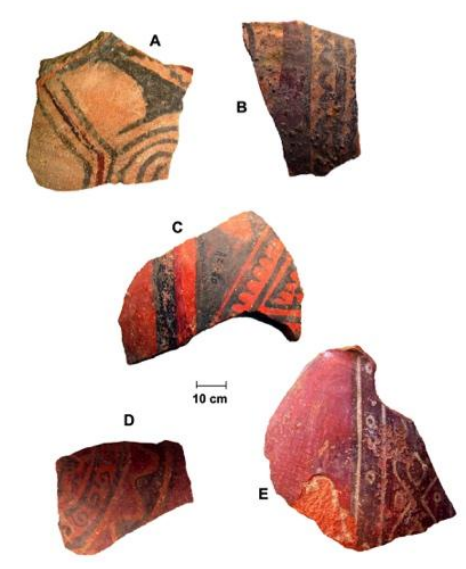

Fig. 2. The Arica cluster styles, Late Intermediate Period (A.D. 1,000 to 1,400): (a-b) San Miguel (samples VIW 435 and VIW 367, see Table A.2), (c) Pocoma (sample VIW 374), (d-e) Gentilar (samples VIW 375 and VIW 393).

The Serrano cluster of high Andes valleys, known as Charcollo style (Romero, 2002)

(Fig. 3). They are common in the upper valleys of Arica and in the highland of Tacna (Gordillo, 1996). It resembles the Estuquiña style, applied upon the slip of deep bowls, in the highlands of the Osmore basin (Stanish, 1992).

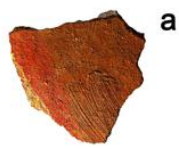

b
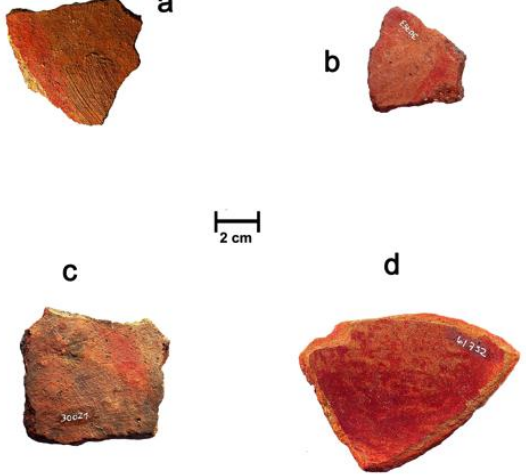

Fig. 3. The Serrano, high Andes valleys, group pottery styles, Late Intermediate Period (A.D. 1,000 to 1,400): (a-c) Charcollo style (samples VIW 392, VIW 417, and 420, see Table A.2), (d) Serrano Crude Red style (sample VIW 411).

The Black/Red cluster includes the Chilpe style (Schiappacasse, et al., 1989). Vessels were made with high-quality technique, distinguishing it as imported goods from the highlands.

\footnotetext{
1 VIW: Lab code, see Table A.1.
} 
Similar designs are described for the Pacaje context in the highland of Bolivia (Pärssinen and Siiriäinen, 1997), as well as for other pre-Inka sites in NCh and the Lake Titicaca basin (Fig. 4).

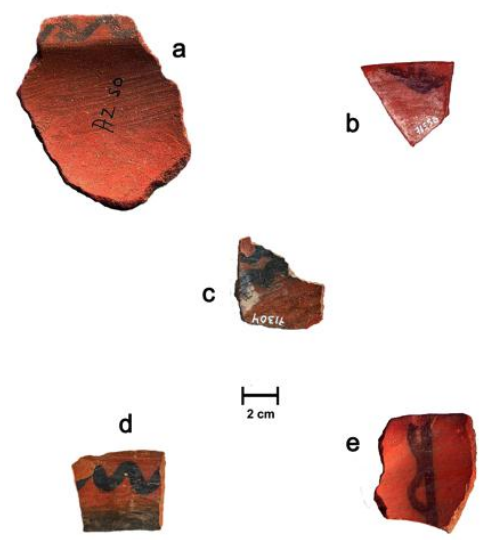

Fig. 4. The Black/Red group, Late Intermediate Period (A.D. 1,000 to 1,400): (a-d) Chilpe style (samples VIW 370, VIW 396, 397, and 412, see Table A.2), (e) Perpendicular Black/Red variety or Vilavila style (sample VIW 390).

\subsubsection{Late Period (A.D. 1,400 - 1,530) pottery styles}

Currently, the Inka styles include Inka Polychrome, Inka Black/Red, Inka Red (Inka Red Coat) and a well-known style called locally as Saxamar and regionally as Inka-Pacaje (Albarracín-Jordan, 1996; Cremonte, et al., 2015; Ryden, 1947). In contrast to the paste of the Arica and Serrano clusters, the vessels of this cluster were made with the finest paste, standard 210, 220, and 500. Paste 210, burned at high temperatures, yielding a high quality pottery with a bright orange color and a polished surface, which typically characterize them along the Andes. Pastes 220 and 500 are represented in fewer quantities. Standard 100 (medium temper, reductive firing) was another paste used for manufacturing of Inka pottery.

The Inka-Pacaje or Saxamar style is characterized by highly stylized llamas densely displayed in a spiral form inside bowls, the polished surface of which is covered with a red slip. A variety of this style corresponds to designs of black circles with white or black dots inside over 
the same type of surface, and displayed in the same way as the llamas. The Inka Polychrome style shows straight linear designs in black, red and white applied over a polished red surface. These fine vessels, typical of the Inka State industry south of Cusco, may have been possibly produced in specialized centers of ollero (pottery maker) communities; (Murra, 2002) in the Lake Titicaca basin, which avoided the need to bring them from Cusco. The Inka Black/Red variant is composed of straight linear black designs applied to a polished surface or covered with a red slip. In some cases, fine black lines were painted on the lip of the vessels, giving them a typical expression. The Inka Red or Inka Red Coat variant corresponds similarly to vessels made with paste standard 210, polished and covered with a red slip. It is recognized among bowls and aryballoids, which do not have any other sort of decoration (Fig. 5).
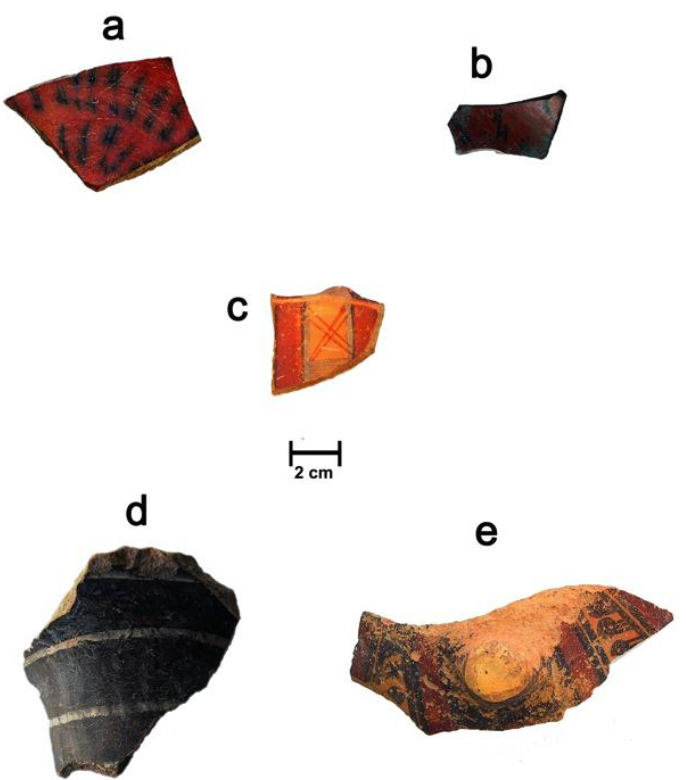

Fig. 5. The Inka pottery styles, Late Period (A.D. 1,300 - 1,530): (a-b) Saxamar or Inka-Pacaje style (Samples VIW 406 and VIW 424, see Table A.2), (c-e) Inka Polychrome style (samples VIW 405, VIW 409, and VIW 410). 
The Indigenous Post Hispanic style (IPH A.D. 1,530 to 1,700) was made in early colonial times, maintaining pre-Columbian techniques and paste characteristics, although lacking the typical local decoration. This pottery is vitrified and is morphologically similar to some Spanish Colonial pottery. The paste of this ceramic was classified as Standard 1000, which has fine grain clay paste with temper burned at high temperature in an oxidant environment. They were manufactured by wheel. We integrate this pottery style in this analysis as an example of the continuity of local pottery production into colonial times.

\section{Materials and Methods for instrumental Neutron Activation Analysis}

\subsection{The analyzed data from the valleys of northern Chile}

Ninety-four fragments of pottery from NCh that constitute the subject of this report is a subset of a larger batch of sherds from Argentina and Bolivia ( $\mathrm{n}=459$, Table 3), which were analyzed as a whole leading to the compositional groups in relation to which the sample results of $\mathrm{NCh}$ are examined. The discussion of this sample subset, considered as an independent analytic unit, enable us to study some issues on Inka expansion to the south (Williams, et al., 2016, unpusblished data). The entire samples belong from Inka provinces in NWA (in the modern Salta, Jujuy, and Catamarca provinces), NCh, and the Bolivian Altiplano. Samples from NWA $(n=306)$ come from Inka and pre Inka excavated sites and surface collection (Williams, et al., 2016). Samples from Bolivia ( $\mathrm{n}=14)$ come from a large archaeological collection excavated by Adolph Bandelier in Lake Titicaca in the Peru and Bolivia high Andean plateau by the end of the 19th century (Bandelier 1910: 2006-2008, Plate XLVIII).

This surface and stratigraphic collections that include pottery are stored in the American Museum of Natural History, from where we obtained the sample analyzed here. Both the 
Argentinian and Bolivian samples were gathered systematically, as we specifically look for typical Inca and pre-Inka vessel fragments. The larger sample includes clay $(\mathrm{n}=45)$, which were solely obtained in Salta (Calchaquí valley), Catamarca (Andalgalá region) and Jujuy (Yavi). We did not have the opportunity to collect and analyzed clay samples from NCh and Lake Titicaca basin, and it should be consider in the future.

Table 3. Frequency distribution of the large batch of analyzed samples.

\begin{tabular}{|c|c|c|c|}
\hline & Pottery & Clay & Total \\
\hline Chile & 94 & - & 94 \\
\hline Argentina & 306 & 45 & 351 \\
\hline Bolivia & 14 & - & 14 \\
\hline Total & 414 & 45 & 459 \\
\hline
\end{tabular}

Northern Chile samples were selected from 23 sites located in the valleys of Azapa, Lluta, and Camarones, and the high Andes valleys of Arica (Fig. 1; Tables A.1, A.2), which cover a wide geographic area and assure that all the ceramic styles (LIP, LP and PHP) were represented in the sample. The selected sites have been identified as LP and LIP based on the occurrence of Inka and LIP style pottery. All these materials are stored at the Museo Arqueológico Universidad de Tarapacá, in Arica, Chile, and were obtained by systematic archaeological studies, carried first by the end of the sixties (Dauelsberg, 1995 [1960]; Focacci, 1995 [1961]). Later, from 1997 to 2000 we carried full coverage survey, surface collection and excavations in the Lluta Valley, which has provided the material sample for this study. Samples from the other sites in the valleys of Camarones, Azapa, and Chaca were obtained from collections in the Museo Universidad de Tarapacá (full references for sites description are provided in Table A.1).

The specific samples for this study were selected systematically to assure a good representation of LP and LIP styles. Forty-eight samples come from thirteen sites that belong to the LIP (A.D. 1,000 - 1,400). Forty-three samples come from nine sites that correspond to the LP 
(A.D. 1,400 - 1,500), whereas the latest three samples come from two PHP sites (A.D. 1,5001.700) (Fig. 1; Table A.1).

\subsection{Technical methods for the chemical composition of pottery}

The neutron activation analysis consists of two irradiations and a total of three gamma counts. It constitutes a superset of the procedures used at most other NAA laboratories (Glascock, 1992; Neff, 1992; Neff, 2000). Pottery samples and clays were prepared for INAA using standard procedures at MURR. Fragments of about $1 \mathrm{~cm}^{2}$ were removed from each sample and abraded using a silicon carbide burr in order to remove glaze, slip, paint, and adhering soil, thereby reducing the risk of measuring contamination. The samples were washed in deionized water and allowed to dry in the laboratory. Once dry, the individual sherds were ground to powder in an agate mortar to homogenize the samples. Two analytical samples were prepared from each source specimen. Portions of approximately $150 \mathrm{mg}$ of powder were weighed into clean high-density polyethylene vials used for short irradiations at MURR. At the same time, $200 \mathrm{mg}$ of each sample was weighed into clean high-purity quartz vials used for long irradiations. The technical method used to conduct the analysis corresponds to a bulk chemical compositional study of the ceramic pastes through INAA, which is the most precise method available at present for determination of the provenience of ceramic. Statistical analysis was subsequently carried out on base-10 logarithms of concentrations on the remaining 28 elements. Use of log concentrations rather than raw data compensates for differences in magnitude between the major elements, such as $\mathrm{Ca}$, and trace elements, such as the rare earth or lanthanide elements (REEs). Transformation to base-10 logarithms also yields a more normal distribution for many trace elements. The interpretation of compositional data obtained from the analysis of archaeological materials is discussed in detail elsewhere (Baxter, 1994; Bieber, et al., 1976; Bishop and Neff, 1989; Glascock, 1992; Harbottle, 
1976; Neff, 2000) and will only be summarized here.

The main goal of data analysis is to identify distinct homogeneous groups within the analytical database. Based on the provenance postulate (Weigand, et al., 1977), different chemical groups may be assumed to represent geographically restricted sources. The ubiquity of ceramic raw materials usually makes it impossible to sample all potential "sources" intensively enough to create groups of known to which unknowns can be compared. Compositional groups can be viewed as "centers of mass" in the compositional hyperspace described by the measured elemental data. Groups are characterized by the locations of their centroids and the unique relationships (i.e., correlations) between the elements. Decisions about whether to assign a specimen to a particular compositional group are based on the overall probability that the measured concentrations for the specimen could have been obtained from that group.

Initial hypotheses about source-related subgroups in the compositional data can be derived from non-compositional information (e.g., archaeological context, decorative attributes, etc.) or from application of various pattern-recognition techniques to the multivariate chemical data. Some of the pattern recognition techniques that have been used to investigate archaeological data sets are cluster analysis (CA), principal components analysis (PCA), and discriminant analysis (DA). The PCA biplot affords a means for assessing the contributions of various elements to the identified subgroup structure. Each of these techniques has proper advantages and disadvantages, which may depend upon the types and quantity of data available for interpretation.

Whether a group can be discriminated easily from other groups can be evaluated visually in two dimensions or statistically in multiple dimensions. A metric known as the Mahalanobis distance (or generalized distance) makes it possible to describe the separation between groups or between individual samples and groups on multiple dimensions. Lastly, Mahalanobis distance calculations are also quite useful for handling missing data (Sayre, 1975). When many specimens 
are analyzed for a large number of elements, it is almost certain that a few element concentrations will be missed for some of the specimens. This occurs most frequently when the concentration for an element is near the detection limit. Rather than eliminate the specimen or the element from consideration, it is possible to substitute a missing value by replacing it with a value that minimizes the Mahalanobis distance for the specimen from the group centroid.

\section{Results of instrumental Neutron Activation Analysis}

The analyses at MURR produced elemental concentration values for 32 or 33 elements in most of the 414 analyzed pottery samples. Data for Ni in most samples was below detection limits (as is the norm for newest World ceramic analyses) and was removed from consideration during the statistical analysis. In addition, $\mathrm{As}, \mathrm{Nd}, \mathrm{U}$, and $\mathrm{Tb}$ have higher counting errors. In order to minimize variation within the dataset, these elements were removed from consideration.

A PCA biplot based on the correlation matrix of the complete data set $(\mathrm{N}=414)$ is shown in Figure 6d. PCA resulted in the identification of five groups: four large groups and one smaller group. Interestingly, these chemical groups correspond to broad geographic zones-Titicaca Basin (Group-1), NCh (Group-2), NWA (Group 3), and an unknown area (Groups X and Y) most of which samples comes from NW Argentina. A similar pattern can be seen in Figure 5, a plot of samarium and europium concentrations. Chemical groups assigned to particular geographic zones do not mean that they were archeologically collected from that area.

Group $1(n=18)$ is assumed to represent pottery produced in the Titicaca basin based on the fact that 9 of the 15 analyzed samples from Titicaca are assigned to Group-1 (Williams et al. 2016). Of the 9 samples assigned to this group, seven are from NCh archaeological contexts and one is from a site in Salta Province. Comparison of Group-1 with D'Altroy and Bishop's (1990) 
INAA for southern Peruvian Inka pottery (specifically the Lake Titicaca pottery samples), previously analyzed at Brookhaven National Laboratory, provide further support that Group-1 pottery originates from the Titicaca basin.

Group $2(n=48)$ is comprised almost exclusively of pottery recovered from sites in NCh. Because this group includes pottery from so many different Chilean sites, it is probable that may subsume multiple compositional groups. Additional sampling will aid in evaluating the homogeneity of this group. Currently, the most conservative approach is to treat this as a single analytical unit until additional analyses from NCh become available.

Group 3 ( $n=203$ ) that constitutes the bulk of the analyzed sample (from NWA) forms a large macro-group.

Group X $(n=20)$ corresponds exclusively from one Inka site in NWA. Group Y $(n=4)$ also come from different sites in NWA (Williams et al. 2016). Although unassigned specimens $(\mathrm{n}=121)$ are problematic, the approach taken herein is similar to that taken by most INAA laboratories and serves to minimize incorrect group assignments by leaving marginal specimens unassigned (Neff, et al., 2006; Fig. 6b).

In reference to the Chilean sample $(\mathrm{n}=94)$ the compositional analysis shows that they distributed within the three of five chemical groups listed above: Group-1 (8.5\%), Group-2 (46.8\%), Group 3 (5.3\%). Thirty-seven samples were unassigned (39.4\%; Table 4), which means that they were marginal to all groups (less than $1 \%$ probability of membership), or that they showed compositional affiliations with more than one group (high probabilities in multiple groups). Our cut-off for group membership is generally $1 \%$, a general rule applied by most INAA MURR projects. Moreover, it could be a specimen that if included in a group to which it apparently belonged might have obscured distinctions between groups that were otherwise well discriminated. A PCA biplot based on the correlation matrix of the five chemical groups are 
shown in Figs. 6a-b. A similar pattern can be seen in Fig. 6c, a plot of samarium and europium concentrations. Other compositional groups related with the total batch of pottery fragments and clay samples (both from NWA) and from Bolivia are not presented here (Williams et al. 2016) . Moreover, sherds are represented by the individual data points assigned to a particular group.

There is no point in designating them separately.
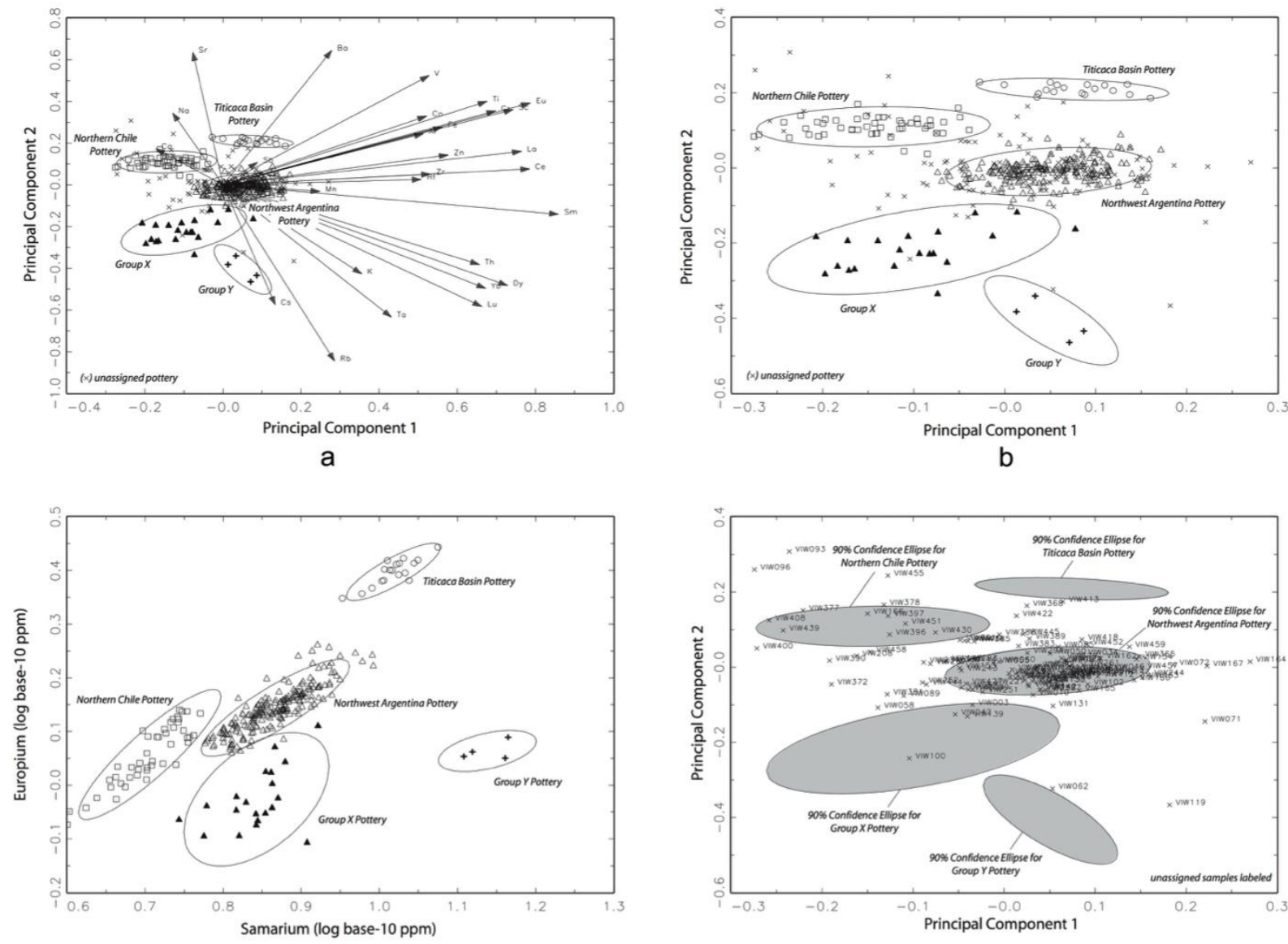

C

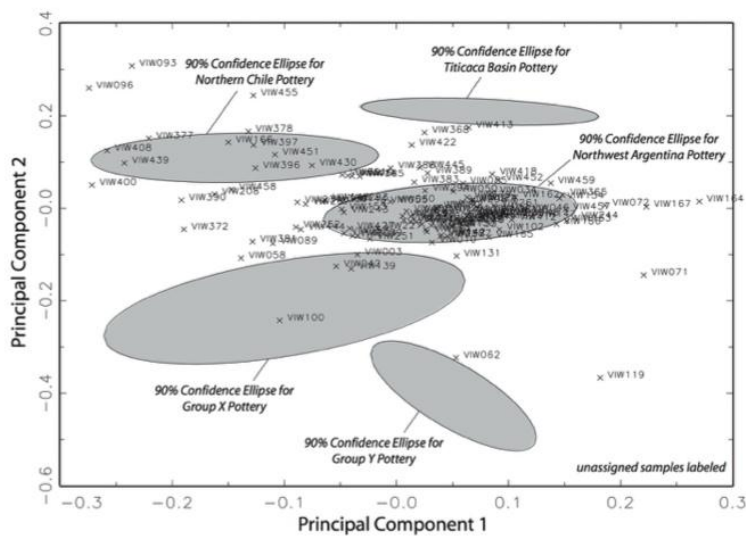

d

Fig. 6. (a) correlation-matrix biplot of principal component 1 and 2 based on PCA of the entire sample dataset $(n=414)$. Ellipses represent the $90 \%$ confidence interval for group membership; (b) correlation-matrix plot of principal component 1 and 2 based on PCA of the entire sample dataset ( $\mathrm{n}=414)$. Ellipses represent the $90 \%$ confidence interval for group membership; (c) plot of samarium and europium base-10 logged concentrations for pottery from NCh, the Titicaca Basin, NWA, and two unknown production areas (pottery Group X and Group Y). Ellipses represent the 90\% confidence interval for group membership; (d) correlation-matrix plot of principal component 1 and 2 based on PCA of the entire sample dataset with unassigned specimens projected against $90 \%$ confidence ellipses for the groups. 
Table 4. Frequency and proportions of compositional chemical groups among pottery clusters of NCh sample.

\begin{tabular}{|c|c|c|c|c|c|c|c|c|c|}
\hline & & \multicolumn{4}{|c|}{ Pottery cluster } & \multirow[b]{2}{*}{ Serrano } & \multirow[b]{2}{*}{ Undecorated } & \multicolumn{2}{|c|}{$\begin{array}{l}\text { Total chemical } \\
\text { group }\end{array}$} \\
\hline & & Arica & Inka & $\begin{array}{c}\text { Black on } \\
\text { Red }\end{array}$ & Posthispanic & & & $\mathrm{N}$ & $\%$ \\
\hline \multirow{4}{*}{$\begin{array}{l}\text { Chemical } \\
\text { group }\end{array}$} & Group 1 & & 8 & & & & & 8 & $8.5 \%$ \\
\hline & Group 2 & 22 & 11 & 4 & 2 & 4 & 1 & 44 & $46.8 \%$ \\
\hline & Group 3 & & 5 & & & & & 5 & $5.3 \%$ \\
\hline & Unassigned & 3 & 22 & 10 & & 1 & 1 & 37 & $39.4 \%$ \\
\hline \multirow{2}{*}{$\begin{array}{l}\text { Total pottery } \\
\text { cluster }\end{array}$} & $\mathrm{N}$ & 25 & 46 & 14 & 2 & 5 & 2 & 94 & \\
\hline & $\%$ & $26.6 \%$ & $48.9 \%$ & $14.9 \%$ & $2.1 \%$ & $5.3 \%$ & $2.1 \%$ & & $100.0 \%$ \\
\hline
\end{tabular}

Half of the sample of NCh is comprised of Inka pottery cluster (48.9\%), while $26.6 \%$ belong to the Arica cluster, and only $14.9 \%$ are Black on Red cluster. The Serrano cluster represents $5.3 \%$ of the sample (Table 4). Eight Chilean fragments belong to Group 1 (see Table A.1). Seven of these are Inka polychrome style, and the remaining one is Inka Red style (Table 5). In this group distinct Inka forms, open and closed, are represented. Comparison of Group 1 with D'Altroy's Mantaro Valley and Titicaca basin samples (analyzed at Brookhaven National Laboratory, BNL) provides further support that Group 1 pottery originated in the Titicaca basin (Bishop and Neff, 1989; D'Altroy and Bishop, 1990). 
Table 5. Distribution of pottery styles through chemical Groups of NCh sample.

\begin{tabular}{|c|c|c|c|c|c|c|c|c|c|c|}
\hline & \multicolumn{2}{|c|}{ Group 1} & \multicolumn{2}{|c|}{ Group 2} & \multicolumn{2}{|c|}{ Group 3} & \multicolumn{2}{|c|}{ Unassigned } & \multicolumn{2}{|c|}{ Total } \\
\hline Late Intermediate Period & $\mathrm{N}$ & $\%$ & $\mathrm{~N}$ & $\%$ & $\mathrm{~N}$ & $\%$ & $\mathrm{~N}$ & $\%$ & $\mathrm{~N}$ & $\%$ \\
\hline Arica & & $\mathbf{0 , 0 \%}$ & 22 & $50,0 \%$ & & $\mathbf{0 , 0 \%}$ & 3 & $8,1 \%$ & 25 & $26,6 \%$ \\
\hline Gentilar & & $0,0 \%$ & 8 & $18,2 \%$ & & $0,0 \%$ & 1 & $2,7 \%$ & 9 & $9,6 \%$ \\
\hline Pocoma & & $0,0 \%$ & 5 & $11,4 \%$ & & $0,0 \%$ & & $0,0 \%$ & 5 & $5,3 \%$ \\
\hline San Miguel & & $0,0 \%$ & 8 & $18,2 \%$ & & $0,0 \%$ & 2 & $5,4 \%$ & 10 & $10,6 \%$ \\
\hline San Miguel T & & $0,0 \%$ & 1 & $2,3 \%$ & & $0,0 \%$ & & $0,0 \%$ & 1 & $1,1 \%$ \\
\hline Black on Red & & $\mathbf{0 , 0 \%}$ & 4 & $9,1 \%$ & & $0,0 \%$ & 10 & $27,0 \%$ & 14 & $14,9 \%$ \\
\hline Black/Red & & $0,0 \%$ & 1 & $2,3 \%$ & & $0,0 \%$ & 2 & $5,4 \%$ & 3 & $3,2 \%$ \\
\hline Black/Red Perpendicular & & $0,0 \%$ & & $0,0 \%$ & & $0,0 \%$ & 1 & $2,7 \%$ & 1 & $1,1 \%$ \\
\hline Chilpe & & $0,0 \%$ & 2 & $4,5 \%$ & & $0,0 \%$ & 5 & $13,5 \%$ & 7 & $7,4 \%$ \\
\hline Vilavila & & $0,0 \%$ & 1 & $2,3 \%$ & & $0,0 \%$ & 2 & $5,4 \%$ & 3 & $3,2 \%$ \\
\hline Serrano & & $\mathbf{0 , 0 \%}$ & 4 & $9,1 \%$ & & $\mathbf{0 , 0 \%}$ & 1 & $2,7 \%$ & 5 & $5,3 \%$ \\
\hline Charcollo & & $0,0 \%$ & 3 & $6,8 \%$ & & $0,0 \%$ & & $0,0 \%$ & 3 & $3,2 \%$ \\
\hline Serrano Crude Red & & $0,0 \%$ & 1 & $2,3 \%$ & & $0,0 \%$ & 1 & $2,7 \%$ & 2 & $2,1 \%$ \\
\hline Undecorated & & $\mathbf{0 , 0 \%}$ & 1 & $2,3 \%$ & & $0,0 \%$ & 1 & $2,7 \%$ & 2 & $2,1 \%$ \\
\hline Undecorated & & $0,0 \%$ & 1 & $2,3 \%$ & & $0,0 \%$ & 1 & $2,7 \%$ & 2 & $2,1 \%$ \\
\hline Late Period & & & & & & & & & & \\
\hline Inka & 8 & $100,0 \%$ & 11 & $25,0 \%$ & 5 & $100,0 \%$ & 22 & $59,5 \%$ & 46 & $48,9 \%$ \\
\hline Inka Black/Red & & $0,0 \%$ & & $0,0 \%$ & & $0,0 \%$ & 2 & $5,4 \%$ & 2 & $2,1 \%$ \\
\hline Inka Polychrome & 7 & $87,5 \%$ & 2 & $4,5 \%$ & & $0,0 \%$ & 6 & $16,2 \%$ & 15 & $16,0 \%$ \\
\hline Inka Red & 1 & $12,5 \%$ & 1 & $2,3 \%$ & 4 & $80,0 \%$ & 8 & $21,6 \%$ & 14 & $14,9 \%$ \\
\hline Inka Red Slip & & $0,0 \%$ & & $0,0 \%$ & 1 & $20,0 \%$ & 1 & $2,7 \%$ & 2 & $2,1 \%$ \\
\hline Saxamar & & $0,0 \%$ & 8 & $18,2 \%$ & & $0,0 \%$ & 3 & $8,1 \%$ & 11 & $11,7 \%$ \\
\hline Saxamar B & & $0,0 \%$ & & $0,0 \%$ & & $0,0 \%$ & 2 & $5,4 \%$ & 2 & $2,1 \%$ \\
\hline Posthispanic & & $0,0 \%$ & 2 & $4,5 \%$ & & $0,0 \%$ & & $\mathbf{0 , 0 \%}$ & 2 & $2,1 \%$ \\
\hline Indigenous Post Hispanic & & $0,0 \%$ & 2 & $4,5 \%$ & & $0,0 \%$ & & $0,0 \%$ & 2 & $2,1 \%$ \\
\hline Total & 8 & $100,0 \%$ & 44 & $100,0 \%$ & 5 & $100,0 \%$ & 37 & $100,0 \%$ & 94 & $100,0 \%$ \\
\hline
\end{tabular}

Forty-four fragments belong to Group 2, which is entirely composed of pottery recovered from sites in NCh. Because this group includes pottery from so many sites, it probably subsumes multiple compositional groups (Table A.1 and Table 4). Additional sampling will aid in evaluating the homogeneity of this group. Currently, the most conservative approach is to treat this as a single group until additional analyses from NCh are available. Stylistically, Group 2 is represented mainly by the Arica ceramic cluster (San Miguel, Early San Miguel, Pocoma and Gentilar styles), with $50 \%$ of the cases, followed by Inka (25\%) and Black on Red clusters (9.1\%) (Table 5).

Five fragments belonging to Group 3 are Inka Red Slip (Table 5). This Group primarily comprises provincial Inka pottery from Salta, and, to a lesser extent, from Catamarca, Jujuy, and the Titicaca basin archaeological sites (Williams et al. 2016). Group 3 is somewhat 
heterogeneous and may include pottery from more than one production locale. Fragments unassigned to a chemical group mostly correspond to Inka styles (59.5\%), and, secondly, to Black on Red style (27\%) (Table 5).

According to Table 5, where the distribution of pottery styles through chemical groups is displayed, 25 cases of Arica ceramic styles, 22 are relatively well represented in Chemical Group 2. Only 3 samples are unassigned, of which two correspond to the San Miguel style and one to the Gentilar style (Table 5).

Regarding the Inka styles (46 cases), it is observed that some diversity is found in Group 2. Of the eleven samples of the Saxamar or Inka Pacaje style, eight belong in Group 2 and three in Unassigned Chemical Group. From the eight specimens assigned to Group 1, seven correspond to the Inka Polychrome style and one to the Inka red style. Five specimens are assigned to Group 3, and four correspond to the Inka Red style and one to Inka Red Slip, most of them aryballus. Therefore, the Inka styles might be referenced to the following chemical groups: Group 1 to Inka Polychrome, Group 2 to Saxamar and Group 3 to Inka Red. Lastly, the Inka style specimens grouped in the Unassigned Chemical Group include several imperial styles, from which the Inka Polychrome and Inka Red styles stand out (Table 5).

Regarding the 14 Black on Red samples, the majority $(n=10)$ corresponds to the Unassigned Group, and four to Group 2. In the unassigned Group, five correspond to the Chilpe style, the remaining sample $(n=5)$ belong in minor number to the other substyles (i.e. Black/Red, Black/Red Perpendicular and Vilavila; see Table 5). The four samples left show affinity with Group 2 (see Table 5). Only two samples come from a site assigned to the Post Hispanic Period (2.1\%; see Table 6).

The 8 samples in Group 1 fully correspond to the LP. Group 2, in contrast, is majority made with samples from the LIP/LP (68.2\%), but also includes LP samples (27.3\%) as well as from the 
PHP (4.5\%). Group 3 exclusively contains samples of sites assigned to the LP Inka styles $(n=5)$.

Unassigned samples mostly come from LP sites (62.2\%) and, to a lesser extent from the LIP (37.8\%) (see Table 6).

Table 6. Chronological distributions of chemical Groups in NCh sample.

\begin{tabular}{|c|c|c|c|c|c|c|c|c|c|c|}
\hline \multirow[b]{2}{*}{ Period } & \multicolumn{2}{|c|}{ Group 1} & \multicolumn{2}{|c|}{ Group 2} & \multicolumn{2}{|c|}{ Group 3} & \multicolumn{2}{|c|}{ Unassigned } & \multicolumn{2}{|c|}{ Total } \\
\hline & $\mathrm{N}$ & $\%$ & $\mathrm{~N}$ & $\%$ & $\mathrm{~N}$ & $\%$ & $\mathrm{~N}$ & $\%$ & $\mathrm{~N}$ & $\%$ \\
\hline LIP/LP & & $0.0 \%$ & 30 & $68.2 \%$ & & $0.0 \%$ & 14 & $37.8 \%$ & 44 & $46.8 \%$ \\
\hline LP & 8 & $100.0 \%$ & 12 & $27.3 \%$ & 5 & $100.0 \%$ & 23 & $62.2 \%$ & 48 & $51.1 \%$ \\
\hline PHP & & $0.0 \%$ & 2 & $4.5 \%$ & & $0.0 \%$ & & $0.0 \%$ & 2 & $2.1 \%$ \\
\hline Total & 8 & $100.0 \%$ & 44 & $100.0 \%$ & 5 & $100.0 \%$ & 37 & $100.0 \%$ & 94 & $100.0 \%$ \\
\hline
\end{tabular}

Finally, the comparison of the clay samples from NW Argentina was made with the larger reference groups. The results show poor match with all of the reference groups - in part because these analyses are derived from untempered raw clays that have not been refined (as would have presumably been the case in large State-controlled Inka workshops). When the NWA clays are projected against the $90 \%$ confidence ellipses for the NCh, Titicaca Basin, NWA, X, and Y compositional pottery groups, most of the clays plot within the NWA ellipse. None of the clays exceed $1 \%$ probability of membership in Groups 1 and 2 indicating that that clay is a poor match with these groups. Future research must include clay samples from northern Chile and Bolivian Altiplano to strengthen the relation between pottery and raw material sources data.

\section{Discussions and Conclusion}

In this manuscript we examined the role of pottery in the expansion of the Inka State into the territories south of Cusco, known as Collasuyu, based on the results of INAA of 94 fragments of pottery from several archaeological sites in NCh. 
The INAA demonstrates that ceramic samples belong to three of the five chemical groups established for larger samples that cover Bolivian Altiplano and NWA (Williams, et al., 2016). The results could be viewed in the context of the political trends that occurred during Inka and pre Inka times. Eight fragment pots of the batch belong to the chemical Bolivian Altiplano Inka Group 1, and correspond, exclusively, to the Inka Polychrome and Inka Red. These vessels are easily recognized for their physical and iconographic characteristics (fine grain paste and temper, oxidant burnish, finely polished surface, with red slip, geometric designs in white, black and red). No Arica local and Serrano styles where made with paste of Group 1. Samples of this Group come from LP locations at the Lluta and Azapa valleys and one from the Inka Tambo of Zapahuira in the Andean foothill. These locations are well known for their relation with Altiplanic groups and the Inka State (Gallardo, 2013; Muñoz, 2005; Pärssinen and Siiriäinen, 1997; Santoro, et al., 2010b; Williams, et al., 2009). This means that Group 1 vessels were possibly made in State pottery centers somewhere at the Lake Titicaca basin, in the Bolivian Altiplano (Alconini, 2013; Spurling, 1992). The distribution of Inka Polychrome vessels over NCh may have occurred through some of the mechanisms of exchange and control of the State (Durston and Hidalgo, 1997; Gallardo, 2013; Santoro, et al., 2010a).

The wide territorial dispersion of the Inka pottery seems to indicate that the State was able to maintain and enhance its control over the territories of $\mathrm{NCh}$, and that the political arrangements were accepted and shown by local potters that imitated Inka style pots using paste (Group 2) of local origin. In other word, the symbols of power embedded in the Inka pots were reproduced by skilled local artisans that learned how to make vessels similar in style to the original Inka ones, but with local paste, that we could sort out through the INAA. One interpretation for this emulation could be that in a later phase of the Inka State administration, local artisans learned to reproduce the State standard for pottery making. Thus, although they did 
not have the clay raw material used in the highlands to make Inka Polychrome vessels (Group 1), they worked hard with the local clay raw material (Group 2) to make Inka vessels with its typical imperial appearance. In this way they combined traditional manufacturing techniques. Vessels made with paste of Group 2 integrate mainly Saxamar or Inka Pacaje, and in a lesser extent, Inka Polychrome and Inka Red styles corresponding to the LP, as well as local pottery styles like the Arica styles (San Miguel, Pocoma, Gentilar, and Late San Miguel), Serrano styles (Huaihuarani, Serrano Crude Red), and Black on Red styles (Chilpe and Perpendicular Black on Red, and Vilavila). This means that the local pottery production lasted throughout the LP and did not disappear. By learning how to make vessels similar in style to the original Inka one, the local artisans reproduced the symbols of power embedded in the Inka pots, but with local paste that we could sort out through the INAA. In other words, although they did not have the fine highland clay raw material used in to make Inka Polychrome vessels, they worked hard with local clay to make vessels with its typical imperial appearance.

In this way traditional manufacturing techniques and foreign styles were combined. Group 2 paste was used for Saxamar or Inka Pacaje, Inka Polychrome and Inka Red styles vessels corresponding to the Late period, as well as local pottery styles like the Arica styles (San Miguel, Pocoma, Gentilar, and Late San Miguel), Serrano styles (Huaihuarani, Serrano Crude Red), and Black on Red styles (Chilpe and Perpendicular Black on Red, and Vilavila). This means that the local pottery production lasted throughout the Inka period and did not disappear. It is certainly a product made under the Inka State standards (see Table A.1).

Another perspective for the exchange networks and labor organization of the State is the appearance of Red Inka vessel made with NWA paste of Group 3, which may correspond to long distance traffic goods, which was not unusual as mullu was brought from the southern coast of Ecuador to the valleys and highland of Arica (Ceruti and Reinhard, 2009; Murra, 2002; Santoro, 
et al., 2010b).

In sum, the analyses have been successful in identifying compositional groups that can be tied to specific geographic regions within the southern Andes as we seen for NCh although future research should focus on the refinement of these chemical groups. Such research will undoubtedly lead to a better understanding of Inka pottery production and distribution in the Southern Andes. We also suggest that future research include a petrographic component to determine if a combined mineralogical and chemical approach can provide a better resolution than what we have shown here, given that studies of sand, rock, and volcanic tempers may yield insights that the INAA analysis could not provide. Future analyses of pottery from NCh will facilitate the identification of additional compositional groups, thereby enabling many of these samples to be assigned to a compositional group.

\section{Acknowledgments}

Work performed in the Archaeometry Lab at MURR was supported in part by a grant from the US National Science Foundation (1415403). In Chile, funding was provided by FONDECYT grants 1030312 (to C.S.), 7030111 and 7040186, and Fundación Antorchas Argentina project $\mathrm{N}^{\circ}$ 4248-45 (to V.W.). CMS acknowledge support from Universidad de Tarapacá through the Laboratorio de Arqueología y Paleoambiente at the Instituto de Alta Investigación, and CONICYT’s Programa de Investigación Asociativa (PIA), Anillo SOC 1405. Final editing was realized in the context of project CONICYT/PAI/Atracción de capital Humano Avanzado del Extranjero, Folio No 80150062. We thank Paola Salgado for drafting Fig. 1, Marco Espinoza for translating part of the text into English and Carolina Santoro for final English editing. 


\section{References}

Adán, L., Uribe, M., 2005. El dominio Inka en las quebradas altas del Loa Superior: Un acercamiento al pensamiento político andino, Estudios Atacameños. Arqueología y Antropología Surandinas 29, 41-66.

Albarracín-Jordan, J., 1996. Tiwanaku: Arqueología Regional y Dinámica Segmentaria, CID/Plural Producciones, La Paz.

Alconini, S., 2013. El territorio Kallawaya y el taller alfarero de Milliraya: evaluación de la producción, distribución e intercambio interregional de la cerámica Inka provincial, Chungara Revista de Antropología Chilena 45, 277-292.

Ballester, B., Gallardo, F., 2011. Prehistoric and historic networks on the Atacama Desert coast (northern Chile), Antiquity 85, 875-889.

Baxter, M.J., 1994. Exploratory Multivariate Analysis in Archaeology, Edinburgh University Press, Edinburgh.

Bieber, A.M.J., Brooks, D.W., Harbottle, G., Sayre, E.V., 1976. Application of multivariate techniques to analytical data on Aegean ceramics, Archaeometry 18, 59-74.

Bishop, R.L., Neff, H., 1989. Compositional data analysis in archaeology, in: Allen, R.O. (Ed.), Archaeological Chemistry IV, Advances in Chemistry Series 220, American Chemical Society, Washington, D.C., pp. 576-586.

Calderari, M., Williams, V., 1991. Re-evaluación de los Estilos Ceramicos Incaicos en el Noroeste Argentino, Comechingonia 9, 73-96.

Ceruti, M.C., Reinhard, J., 2009. Inca Rituals and Sacred Mountains, Cotsen Institute of Archaeology, Los Angeles. 
Couso, M.G., Moralejo, R.A., Giovannetti, M., del Papa, L.M., Páez, M.C., Gianelli, J., Raffino, R.A., 2011. Análisis de la variabilidad material del Recinto 1-Kancha II: aportes para una comprensión de la política incaica en El Shincal de Quimivil, Arqueología 17, 35-56.

Covey, A.R., 2000. Inka administration of the far south coast of Perú, Latin American Antiquity $11,119-138$.

Cremonte, M.B., Maro, G., Díaz, A.M., 2015. Acercamiento a la producción y distribución del estilo Inca Pacajes. Un estudio arqueométrico de las pastas, Chungara Revista de Antropología Chilena 47, 387-400.

D'Altroy, T.N., Bishop, R., 1990. The provincial organization of Inka ceramic production, American Antiquity 55, 120-137.

D'Altroy, T.N., Williams, V.I., Lorandi, A.M., 2007. The Inkas in the southlands, in: Morris, C., Burger, R.L., Matos Mendieta, R. (Eds.), Variations in the Expression of Power in the Inka Empire, Dumbarton Oaks, Washington DC, pp. 88-135.

Dauelsberg, P., 1983. Investigaciones arqueológicas en la sierra de Arica, sector Belén, Chungara $11,63-84$

Dauelsberg, P., 1995 [1960]. Reconocimiento arqueológico de los valles de Lluta, Vitor y la zona costera de Arica, Boletín del Museo Regional de Arica 4, 70-77.

Espinoza Soriano, W., 1970. Los mitmas yungas de Collique en Cajamarca, Siglos XV, XVI y XVII, Revista del Museo Nacional. Lima 36, 9-57.

Focacci, G., 1981. Descripción de un cementerio incaico en el valle de Azapa, Chungara 7, 212216.

Focacci, G., 1995 [1961]. Informe sobre excavaciones en San Miguel de Azapa por el Museo Regional de Arica, Boletín Museo Regional de Arica 6, 114-147. 
Glascock, M.D., 1992. Characterization of archaeological ceramics at MURR by neutron activation analysis and multivariate statistics, in: Neff, H. (Ed.), Chemical Characterization of Ceramic Pastes in Archaeology, Prehistory Press, Madison, WI., pp. 11-26.

Gordillo, J., 1996. Miculla, Petroglifos: la Magia de los Signos, EPF Editores, Tacna. Harbottle, G., 1976. Activation analysis in archaeology, Radiochemistry 3, 33-72.

Hayashida, F., Häusler, W., Riederer, J., Wagner, U., 2003. Technology and organisation of Inka pottery production in the Leche Valley. Part II: Study of fired vessels, Hyperfine Interactions 150, 153-163.

Hidalgo, J., Focacci, G., 1986. Multietnicidad en Arica, S. XVI. Evidencias etnohistóricas y arqueológicas, Chungara 16-17, 137-147.

Hyslop, J., 1990. Inka Settlement Planning, University of Texas Press, Austin.

Ixer, R., Lunt, S., Sillar, B., Thompson, P., 2014. Microscopic rocks and expansive empires: Investigating Inca ceramics from Cuzco, Peru, Archaeology International 17, 122-136.

Jiménez de la Espada, M., 1965. Relaciones Geográficas de Indias: Perú, Ediciones Atlas, Madrid.

Julien, C., 1983. Hatunqolla: A View of Inca Rule from the Lake Titicaca Region, University of California Press, Berkeley and Los Angeles.

Llagostera, A., 2010. Retomando los límites y las limitaciones del “Archipiélago Vertical”, Chungara, Revista de Antropología Chilena 42, 283-295.

Morris, C., 1972. El almacenaje en dos aldeas de los Chupaychu, in: Murra, J. (Ed.), Visita de la Provincia de León de Huánuco en 1562, Iñigo Ortiz de Zúñiga, Visitador, Universidad Nacional Hermilio Valdizán, Huanuco, pp. 385-404. 
Morris, C., 1995. Symbols to power: styles and media in the Inka state, in: Carr, C., Neitzel, J.E. (Eds.), Style, Society, and Person. Arcaheological and Ethnological Perspectives, Plenum, New York, pp. 419-433

Morris, C., Thompson, D., 1985. Huánuco Pampa. An Inka City and Its Hinterland, Thames and Hudson, New York.

Muñoz, I., Chacama, J., 2010. El análisis arquitectónico como indicador cultural, precordillera de Arica, siglos X al XV, Actas del XVII Congreso Nacional de Arqueología Chilena, Ediciones Kultrún, Sociedad Chilena de Arqueología, Universidad Austral de Chile, Valdivia, pp. 907-918. Murra, J.V., 1978. La Organización Económica del Estado Inca, Siglo XXI, México D.F. Murra, J.V., 2002. El Mundo Andino. Población, Medio Ambiente y Economía, Fondo Editorial Pontificia Universidad Católica del Perú e Instituto de Estudios Peruanos, Lima.

Neff, H., 1992. Introduction, in: Neff, H. (Ed.), Chemical Characterization of Ceramic Pastes in Archaeology, Prehistory Press, Madison, WI, pp. 1-10.

Neff, H., 2000. Neutron activation analysis for provenance determination in archaeology, in: Ciliberto, E., Spoto, G. (Eds.), Modern Analytical Methods in Art and Archaeology, John Wiley and Sons, Inc., New York, pp. 81-134 Neff, H., Blomster, J., Glascock, M.D., Bishop, R.D., Blackman, M.J., Coe, M.D., Cowgill, G.L., Diehl, R.A., Houston, S., Joyce, A.A., Lipo, C.P., Stark, B.L., Winter, M., 2006. Methodological issues in the provenance investigation of early Formative Mesoamerican ceramics, Latin American Antiquity.

Pärssinen, M., Siiriäinen, A., 1997. Inka-Style ceramics and their chronological relationship to the Inka expansion in the southern Lake Titicaca area (Bolivia), Latin American Antiquity 8, 255-271.

Raffino, R.A., 2004. El Shincal de Quimivil, Editorial Sarquís, San Fernando de Catamarca. 
Romero, Á., 2002. Cerámica doméstica del valle de Lluta: cultura local y redes de interacción Inka, Chungara, Revista de Antropología Chilena 34, 191-213.

Romero, Á., 2005. Organización Social y Economía Política en la Prehistoria Tardía de los Valles de Arica (1.100 - 1.530 D. C.), Memoria para optar al Título Profesional de Arqueólogo, Departamento de Antropología, Universidad de Chile, Santiago.

Ryden, S., 1947. Archaeological Researches in the Highlands of Bolivia, Elanders Boktryckery Aktiebolag, Goteborg.

Santoro, C.M., 2016. Late Prehistoric Regional Interaction and Social Change in a Coastal Valley of Northern Chile, BAR International Series, Oxford.

Santoro, C.M., Dillehay, T.D., Hidalgo, J., Valenzuela, D., Romero, Á., Rothhammer, F., Standen, V.G., 2010a. Revisita al tercer caso de verticalidad de John Murra en las costas de los Andes centrales y centro sur, Chungara, Revista de Antropología Chilena 42, 325-340. Santoro, C.M., Romero, Á., Rosello, E.F., Standen, V.G., Santos, M., Torres, A., 2000. Catastro de Sitios Arqueológicos del Valle de Lluta. Proyecto Fondecyt 1970597. Manuscrito en posesión de los autores.

Santoro, C.M., Romero, Á., Santos, M., 2001. Formas cerámicas e interacción regional durante los períodos Intermedio Tardío y Tardío en el valle de Lluta, in: Berenguer, J., Cornejo, L.E., Gallardo, F., Sinclaire, C. (Eds.), Segundas Jornadas de Arte y Arqueología, Museo Chileno de Arte Precolombino, Santiago, pp. 15-40.

Santoro, C.M., Williams, V., Valenzuela, D., Romero, Á., Standen, V.G., 2010b. An archaeological perspective on the Inka provincial administration of the south central Andes, in: Malpass, M.A., Alconini, S. (Eds.), Distant Provinces in the Inka Empire: Toward a Deeper Understanding of Inka Imperialism, University of Iowa Press, Iowa, pp. 44-74. 
Sayre, E.V., 1975. Brookhaven Procedures for Statistical Analyses of Multivariate Archaeometric Data, Brookhaven National Laboratory Report BNL-23128, New York.

Schiappacasse, V., Castro, V., Niemeyer, H., 1989. Los Desarrollos Regionales en el Norte Grande (1.000 - 1.400 d.C.), in: Hidalgo, J., Schiappacasse, V., Niemeyer, H., Aldunate, C., Solimano, I. (Eds.), Culturas de Chile. Prehistoria, desde sus Orígenes hasta los Albores de la Conquista, Editorial Andrés Bello, Santiago, pp. 181-220.

Schiappacasse, V., Niemeyer, H., 1989. Avances y sugerencias para el conocimiento de la prehistoria tardía de la desembocadura del Valle de Camarones (Región de Tarapacá), Chungara 22, 63-84.

Sillar, B., Dean, E., 2002. Identidad étnica bajo el dominio inka: una evaluación arqueológica y etnohistórica de las repercusiones del Estado Inka en el grupo étnico Canas, Boletín de Arqueología PUCP 6, 205-264.

Spurling, G.E., 1992. The Organization of Craft Production in the Inca State: The Potters and Weavers of Milliraya, Ph.D. Dissertation, Department of Anthropology, Cornell University, University Microfilms, Ann Arbor.

Stanish, C., 1992. Ancient Andean Political Economy, University of Texas Press, Austin. Uribe, M., 1999. La cerámica de Arica 40 años después de Dauelsberg, Chungara, Revista de Antropología Chilena 31, 189-228.

Uribe, M., Urbina, S., 2009. Cerámica y arquitectura pública en el camino del inka del desierto de Atacama (río Loa, Norte Grande de Chile), Revista Chilena de Antropología 20, 227-260. Villanueva, J., 2015. Evaluando la frontera pacajes-carangas para el período Intermedio Tardío (1.100-1.450 d.c.) en el altiplano boliviano central a partir de análisis de pastas cerámicas, Chungara Revista de Antropología Chilena 47, 211-218. 
Weigand, P.C., Harbottle, G., Sayre, E.V., 1977. Turquoise sources and source analysis: Mesoamerica and the southwestern U.S.A, in: Earle, T.K., Ericson, J.E. (Eds.), Exchange Systems in Prehistory, Academic Press, New York, pp. 15-34.

Williams, V., Santoro, C.M., Romero, Á., Gordillo, J., Valenzuela, D., Standen, V.G., 2009. Dominación Inca en los Valles Occidentales (sur del Perú y norte de Chile) y el Noroeste Argentino, Arqueología del Área Centro Sur Andina. Actas del Simposio Internacional. Arequipa, Perú 7, 615-654.

Williams, V.I., 2004. Poder estatal y cultura material en el Collasuyo, Boletín de Arqueología PUCP 8, 209-245.

Williams, V.I., 2010. Uso del espacio a nivel estatal en el sur del Tawantinsuyu, in: Albeck, M.E., Scattolin, M.C., Korstanje, M.A. (Eds.), El Hábitat Prehispánico, Facultad de Humanidades y Ciencias Sociales, Universidad Nacional de Jujuy, San Salvador de Jujuy, pp. 77-114.

Williams, V.I., D'Altroy, T.N., Neff, H., Speakman, J., Glascock, M., 2016. Provisioning the Inka economy in Qollasuyu: production and distribution of ceramics at Inka sites in the southern Andes, Buenos Aires.

Williams, V.I., Lorandi, A.M., 1986. Evidencias funcionales de un establecimiento incaico en el Noroeste argentino, Comechingonia Número Especial, 133-148.

Zori, C., Urbina, S., 2014. Architecture and empire at late prehispanic Tarapacá Viejo, northern Chile, Chugara Revista de Antropología Chilena 46, 211-232. 
Table A.1. Frequency of samples by site and periods: Late Intermediate period and Late period (LIP/LP), Late Period (LP), and Late period and Posthispanic period (LP/PHP).

\begin{tabular}{|c|c|c|c|}
\hline Site LIP/LP & Site type & Period & \# samples \\
\hline Lluta 1 (Santa Lucía) ${ }^{1}$ & Cemetery & LIP/LP & 1 \\
\hline Lluta 21 (Millune) ${ }^{1}$ & Camp & LIP/LP & 1 \\
\hline Lluta 12 (Oleoducto) ${ }^{1}$ & Camp & LIP/LP & 2 \\
\hline Lluta 44 (Molino Calacala) ${ }^{1}$ & Camp & LIP/LP & 2 \\
\hline Lluta 45 (Cardones) ${ }^{1}$ & Cemetery & LIP/LP & 2 \\
\hline Playa Miller- $4^{2}$ & Cemetery & LIP/LP & 2 \\
\hline Azapa-8 (San Miguel) ${ }^{3}$ & Cemetery & LIP/LP & 3 \\
\hline Azapa-50 (Chilpe) ${ }^{1}$ & Camp & LIP/LP & 5 \\
\hline Azapa-58 (Achuyo) ${ }^{1}$ & Camp & LIP/LP & 6 \\
\hline 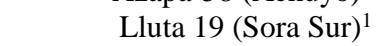 & Camp & LIP/LP & 6 \\
\hline 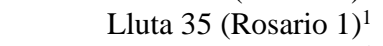 & Camp & LIP/LP & 8 \\
\hline Huaihuarani ${ }^{4}$ & Camp & LIP/LP & 10 \\
\hline Lluta 54 (Huaylacán) ${ }^{5}$ & Cemetery & LIP/LP & 3 \\
\hline Subtotal & & 13 sites & 48 \\
\hline \multicolumn{4}{|l|}{ Site LP } \\
\hline Tambo Zapahuira $^{1}$ & Camp & LP & 2 \\
\hline Camarones $9^{5}$ & Cemetery & LP & 2 \\
\hline Lluta 41 (Chapisca) ${ }^{1}$ & Camp & LP & 2 \\
\hline Lluta 48 (Bocanegra km 40) ${ }^{1}$ & Cemetery & LP & 2 \\
\hline Lluta 36 (Rosario 2$)^{1}$ & Camp & LP & 3 \\
\hline Lluta 47 (Bocanegra Bajo) ${ }^{5}$ & Cemetery & LP & 3 \\
\hline Lluta 34 (Caquena Este) ${ }^{1}$ & Camp & LP & 6 \\
\hline Azapa-15 (Alto Ramírez) & Cemetery & LP & 10 \\
\hline Cachicoca $^{1}$ & Camp & LP & 10 \\
\hline Subtotal & & 9 sites & 43 \\
\hline \multicolumn{4}{|l|}{ Sites LP/PHP } \\
\hline Lluta $24(\text { Challallapo A })^{1}$ & Camp & LP/PHP & 1 \\
\hline Lluta 3 (Parcela Villa Olga) ${ }^{1}$ & Camp & LP/PHP & 2 \\
\hline Subtotal & & 2 sites & 3 \\
\hline Total & & 24 sites & 94 \\
\hline
\end{tabular}

${ }^{1}$ Archaeological studied by our team. Sites in the Lluta valley correspond to a full coverage survey. The other sites were found through rather systematic and opportunistic surveys (Santoro, et al., 2000).

2 Archaeological excavations by Guillermo Focacci during the 1980's (Hidalgo and Focacci, 1986).

${ }^{3}$ Excavation carried out by Guillermo Focacci in 1960 (Focacci, 1995 [1961]).

${ }^{4}$ Surface collection by Dauelsberg (1983).

${ }^{5}$ Unpublished excavations by Dauelsberg during the 1980's.

${ }^{6}$ Excavation carried by Guillermo Focacci 1960 (Focacci, 1981). 
Table A.2. Descriptive features of the 94 pottery fragments analyzed from 23 archaeological sites the lowland and highland of Arica (Romero et al. 2002; Santoro et al. 2001) (see Fig. 1).

\begin{tabular}{|c|c|c|c|c|c|c|c|}
\hline$L a b \#$ & Id & Ceramic Style & Provenience & Paste* & Chemical Group & Shape & Fragment sherd \\
\hline VIW 366 & 1 & Pocoma & Azapa-8 & 220 & Group 2 & Jar & Body \\
\hline VIW 367 & 2 & San Miguel & Playa Miller-4 & 400 & Group 2 & Jar & Body \\
\hline VIW 368 & 3 & San Miguel & Azapa-8 & 400 & Unassigned & Jar & Body \\
\hline VIW 369 & 4 & Gentilar & Playa Miller-4 & 220 & Group 2 & Jar & Body \\
\hline VIW 370 & 5 & Chilpe & Azapa-50 & 400 & Group 2 & Bowl & Rim \\
\hline VIW 371 & 6 & San Miguel & Azapa-50 & 400 & Group 2 & Jar & Body \\
\hline VIW 372 & 7 & Vilavila & Azapa-50 & 500 & Unassigned & Bowl & Base \\
\hline VIW 373 & 8 & Gentilar & Azapa-50 & 220 & Group 2 & Jar & Body \\
\hline VIW 374 & 9 & Pocoma & Azapa-50 & 400 & Group 2 & Jar & Body \\
\hline VIW 375 & 10 & Gentilar & Azapa-8 & 220 & Group 2 & Jar & Body \\
\hline VIW 376 & 11 & Undecorated & Lluta 54 & 400 & Group 2 & Closed pot & Body \\
\hline VIW 377 & 12 & Undecorated & Lluta 54 & 100 & Unassigned & Closed pot & Body \\
\hline VIW 378 & 13 & Inka Polychrome & Azapa-15 & 220 & Unassigned & Pot bowl & Rim \\
\hline VIW 379 & 14 & Inka Polychrome & Azapa-15 & 220 & Unassigned & Pot with handle & $\operatorname{Rim}$ \\
\hline VIW 380 & 15 & Saxamar & Camarones-9 & 210 & Unassigned & Flat bowl & Rim \\
\hline VIW 381 & 16 & Inka Red & Camarones-9 & 210 & Unassigned & Aryballus, & Rim \\
\hline VIW 382 & 17 & Saxamar & Azapa-15 & 210 & Group 2 & Flat bowl & Body \\
\hline VIW 383 & 18 & Inka Black/Red & Azapa-15 & 210 & Unassigned & Pot & Rim \\
\hline VIW 384 & 19 & Saxamar & Azapa-15 & 210 & Group 2 & Flat bowl & Rim \\
\hline VIW 385 & 20 & Inka Red & Azapa-15 & 210 & Unassigned & Flat bowl & Rim \\
\hline VIW 386 & 21 & Inka Red & Lluta 54 & 210 & Group 1 & Aryballus & Rim \\
\hline VIW 387 & 22 & Inka Red Slip & Azapa-15 & 100 & Group 3 & Closed pot & Body \\
\hline VIW 388 & 23 & Saxamar & Lluta 34 & 210 & Unassigned & Flat bowl & Rim \\
\hline VIW 389 & 24 & Inka Polychrome & Lluta 47 & 210 & Unassigned & Flat bowl & Rim \\
\hline VIW 390 & 25 & Vilavila & Lluta 19 & 220 & Unassigned & Bowl & Rim \\
\hline VIW 391 & 26 & Inka Red & Lluta 34 & 210 & Unassigned & Aryballus & Rim \\
\hline VIW 392 & 27 & Charcollo & Lluta 19 & 500 & Group 2 & Closed pot & Body \\
\hline VIW 393 & 28 & Gentilar & Lluta 19 & 400 & Group 2 & Jar & Body \\
\hline VIW 394 & 29 & Gentilar & Lluta 45 & 220 & Group 2 & Jar & Body \\
\hline VIW 395 & 30 & Vilavila & Lluta 44 & 220 & Group 2 & Bowl & $\operatorname{Rim}$ \\
\hline VIW 396 & 31 & Chilpe & Lluta 44 & 220 & Unassigned & Bowl & $\operatorname{Rim}$ \\
\hline VIW 397 & 32 & Chilpe & Lluta 41 & 220 & Unassigned & Bowl & Rim \\
\hline VIW 398 & 33 & Indigenous Post Hispanic & Lluta 3 & 1000 & Group 2 & Dish & Rim \\
\hline VIW 399 & 34 & Saxamar & Tambo Zapahuira & 210 & Group 2 & Flat bowl & Body \\
\hline VIW 400 & 35 & Serrano Crude Red & Lluta 19 & 220 & Unassigned & Bowl & Body \\
\hline VIW 401 & 36 & Inka Polychrome & Lluta 48 & 210 & Group 2 & Aryballus & $\operatorname{Rim}$ \\
\hline VIW 402 & 37 & San Miguel & Lluta 19 & 400 & Group 2 & Jug & Body \\
\hline VIW 403 & 38 & Saxamar & Lluta 47 & 210 & Group 2 & Bowl & Rim \\
\hline VIW 404 & 39 & Inka Polychrome & Lluta 34 & 210 & Group 1 & Bowl & Rim \\
\hline VIW 405 & 40 & Inka Polychrome & Lluta 34 & 210 & Group 1 & Flat bowl & Rim \\
\hline
\end{tabular}




\begin{tabular}{|c|c|c|c|c|c|c|c|}
\hline VIW 406 & 41 & Saxamar & Lluta 3 & 210 & Group 2 & Flat bowl & Base \\
\hline VIW 407 & 42 & Indigenous post Hispanic & Lluta 24 & 1000 & Group 2 & Dish & Body \\
\hline VIW 408 & 43 & Chilpe & Lluta 19 & 220 & Unassigned & Bowl & Rim \\
\hline VIW 409 & 44 & Inka Polychrome & Lluta 41 & 210 & Group 1 & Aryballus & Neck \\
\hline VIW 410 & 45 & Inka Polychrome & Lluta 34 & 210 & Group 1 & Aryballus & Body \\
\hline VIW 411 & 46 & Serrano Crude Red & Lluta 12 & 500 & Group 2 & Bowl & Base \\
\hline VIW 412 & 47 & Chilpe & Lluta 45 & 210 & Unassigned & Bowl & Rim \\
\hline VIW 413 & 48 & San Miguel & Lluta 48 & 400 & Unassigned & Jar & Body \\
\hline VIW 414 & 49 & Inka Red & Lluta 47 & 210 & Unassigned & Aryballus & Rim \\
\hline VIW 415 & 50 & Saxamar & Huaihuarani & 210 & Group 2 & Bowl & Rim \\
\hline VIW 416 & 51 & Saxamar & Azapa-58 & 210 & Unassigned & Bowl & Rim \\
\hline VIW 417 & 52 & Charcollo & Huaiharani & 300 & Group 2 & Jar & Body \\
\hline VIW 418 & 53 & Inka Polychrome & Huaihuarani & 210 & Unassigned & Flat bowl & Rim \\
\hline VIW 419 & 54 & Pocoma & Huaihuarani & 400 & Group 2 & Jug & Body \\
\hline VIW 420 & 55 & Charcollo & Huaihuarani & 400 & Group 2 & Jug & Body \\
\hline VIW 421 & 56 & Gentilar & Huaihuarani & 220 & Group 2 & Jar & Rim \\
\hline VIW 422 & 57 & Chilpe & Huaihuarani & 220 & Unassigned & Bowl & Rim \\
\hline VIW 423 & 58 & San Miguel & Huaihuarani & 400 & Group 2 & Jug & Body \\
\hline VIW 424 & 59 & Saxamar & Huaihuarani & 210 & Group 2 & Bowl & Body \\
\hline VIW 425 & 60 & Chilpe & Lluta 35 & 220 & Group 2 & Bowl & Rim \\
\hline VIW 426 & 61 & Inka Polychrome & Lluta 35 & 210 & Group 1 & Bowl & Base \\
\hline VIW 427 & 62 & Black/Red & Lluta 36 & 220 & Unassigned & Jar & Body \\
\hline VIW 428 & 63 & Pocoma & Lluta 35 & 400 & Group 2 & Jug & Body \\
\hline VIW 429 & 64 & Gentilar & Lluta 35 & 220 & Group 2 & Jar & Body \\
\hline VIW 430 & 65 & Inka Red & Lluta 36 & 210 & Unassigned & Aryballus & Rim \\
\hline VIW 431 & 66 & San Miguel & Lluta 36 & 400 & Group 2 & Jar & Body \\
\hline VIW 432 & 67 & Inka Polychrome & Tambo Zapahuira & 220 & Group 1 & Aryballus & Body \\
\hline VIW 433 & 68 & Inka Red & Undetermined & 210 & Group 3 & Aryballus & Body \\
\hline VIW 434 & 69 & Inka Red & Undetermined & 210 & Group 3 & Aryballus & Rim \\
\hline VIW 435 & 70 & San Miguel & Azapa-58 & 400 & Group 2 & Jug & Body \\
\hline VIW 436 & 71 & Inka Red & Lluta 21 & 210 & Group 3 & Aryballus & Body \\
\hline VIW 437 & 72 & Saxamar & Lluta 35 & 210 & Group 2 & Bowl & Rim \\
\hline$V I W 438$ & 73 & Pocoma & Azapa-58 & 400 & Group 2 & Jar & Body \\
\hline VIW 439 & 74 & Gentilar & Lluta 35 & 220 & Unassigned & Jar & Body \\
\hline VIW 440 & 75 & San Miguel & Lluta 35 & 400 & Group 2 & Jar & Body \\
\hline$V I W 441$ & 76 & Inka Red & Lluta 34 & 210 & Group 3 & Aryballus & Rim \\
\hline VIW 442 & 77 & Black/Red & Huaihuarani & 220 & Group 2 & Jar & Body \\
\hline$V I W 443$ & 78 & San Miguel T & Lluta 1 & 400 & Group 2 & Jar & Body \\
\hline$V I W 444$ & 79 & Saxamar B & Lluta 35 & 210 & Unassigned & Flat bowl & Rim \\
\hline$V I W 445$ & 80 & Inka Red & Azapa-58 & 210 & Unassigned & Aryballus & Body \\
\hline VIW 446 & 81 & Gentilar & Azapa-58 & 220 & Group 2 & Jar & Body \\
\hline VIW 447 & 82 & San Miguel & Lluta 12 & 400 & Group 2 & Jar & Body \\
\hline VIW 448 & 83 & Inka Polychrome & Azapa-58 & 210 & Unassigned & Flat bowl & Base \\
\hline VIW 449 & 84 & Inka Red & Azapa-15 & 210 & Group 2 & Aryballus & Handle \\
\hline VIW 450 & 85 & Inka Polychrome & Azapa-15 & 210 & Group 1 & Flat bowl & Base \\
\hline
\end{tabular}




\begin{tabular}{|c|c|c|c|c|c|c|c|}
\hline VIW 451 & 86 & Inka Black/Red & Azapa-15 & 210 & Unassigned & Flat bowl & Body \\
\hline VIW 452 & 87 & Inka Polychrome & Undetermined & 210 & Unassigned & Flat bowl & Rim \\
\hline VIW 453 & 88 & Inka Polychrome & Undetermined & 210 & Group 2 & Aryballus & Body \\
\hline VIW 454 & 89 & Inka Red & Undetermined & 210 & Unassigned & Aryballus & Body \\
\hline VIW 455 & 90 & Inka Red Slip & Undetermined & 500 & Unassigned & Flat bowl & Rim \\
\hline VIW 456 & 91 & Black/Red & Undetermined & 210 & Unassigned & Flat bowl & Body \\
\hline VIW 457 & 92 & Saxamar B & Undetermined & 210 & Unassigned & Flat bowl & Body \\
\hline VIW 458 & 93 & Black/Red Perpendicular & Undetermined & 220 & Unassigned & Flat bowl & Rim \\
\hline VIW 459 & 94 & Inka Red & Undetermined & 220 & Unassigned & Flat bowl & Rim/base \\
\hline
\end{tabular}

